\title{
Induction of accessory corpus luteum in cows by gonadotropin-releasing hormone administrated after insemination
}

\author{
Darja Musilová, Jan Bartoněk, Svatopluk Čech, Tomáš Páleník, Radovan Doležel \\ University of Veterinary and Pharmaceutical Sciences Brno, Faculty of Veterinary Medicine, \\ Clinic of Ruminant and Swine Diseases, Brno, Czech Republic
}

Received May 10, 2013

Accepted January 23, 2014

\begin{abstract}
Sufficiency of progesterone limits conception rate in dairy cows. This study evaluates the effect of gonadotropin-releasing hormone on induction of accessory corpus luteum, progesterone concentrations and pregnancy in dairy cows. The hormone $(0.05 \mathrm{mg})$ was administrated intramuscularly to cows with one corpus luteum on day 5-7 (Group E1, n=57) or 11-13 (Group E2, $\mathrm{n}=40)$ after insemination; control groups $\mathrm{C} 1(\mathrm{n}=54)$ and $\mathrm{C} 2(\mathrm{n}=41)$ were not treated. Detection of pregnancy by ultrasound examination and measurement of serum progesterone concentration was performed on day 25-39 and around day 90 after insemination. The occurrences of two corpora lutea in groups E1 and E2 versus $\mathrm{C} 1$ and $\mathrm{C} 2$ were $43.9 \%$ and $33.5 \%$ vs. $3.7 \%$ and $9.8 \%(P<0.001)$. Progesterone concentrations were $5.9 \pm 2.92 \mathrm{ng} / \mathrm{ml}$ and $7.8 \pm 2.35 \mathrm{ng} / \mathrm{ml}$ in untreated and treated cows $(P=0.016)$, respectively. Conception rates in groups E1 and E2 were $100 \%$ and $86.7 \%$ in cows bearing two corpora lutea, and only $16.7 \%$ and $38.9 \%$ in cows bearing one corpus luteum $(P<0.01)$; similarly as in groups E1 and E2 compared to groups $\mathrm{C} 1$ and $\mathrm{C} 2(49.1 \%$ and $50 \%$ vs. $50 \%$ and $31.7 \%$ ). Pregnancy rates around day 90 in groups E1 and E2 compared to groups $\mathrm{C} 1$ and $\mathrm{C} 2$ were $45.6 \%$ and $45 \%$ vs. $42.6 \%$ and $26.8 \%$, respectively. Administration of gonadotropin-releasing hormone on day 5-7 or 11-13 after insemination was efficient to induce accessory corpus luteum and increase the concentration of serum progesterone but had no effect on the conception rate.
\end{abstract}

Dairy cow, lecirelin, follicle, progesterone, conception rate

Over the past five decades the pregnancy rate in dairy cows rapidly decreased while milk production increased (Walsh et al. 2011). Early embryo mortality is considered the main cause of low conception rate (Inskeep and Dailey 2005). It has been explored that the concentration of progesterone in peripheral blood is important for the maintenance of pregnancy because progesterone controls embryo development and the luteolytic mechanism (Mann and Lamming 1999). Increased milk production in dairy cows is connected with increased general metabolism as well as with increased progesterone metabolism in the liver which decreases progesterone concentration in peripheral blood (Rhinehart et al. 2009). Progesterone insufficiency can be an important factor responsible for the decrease of the conception rate in dairy cows. Progesterone concentration can be increased by quality improvement of the corpus luteum (CL), administration of progesterone or the induction of accessory corpus luteum (López-Gatius et al. 2004).

The aim of this study was to evaluate the efficiency of the induction of accessory corpus luteum by the administration of gonadotropin-releasing hormone $(\mathrm{GnRH})$ in defined stages of follicle development on day 5-7 or 11-13 after insemination and to evaluate the effect of accessory corpora lutea on progesterone concentrations and conception rates in dairy cows.

\section{Materials and Methods}

Experimental animals

The study was performed on four commercial Holstein-Friesian dairy herds (number of heads per farm was 250-600 cows) from April to September 2012. Mean milk production of the herds ranged from 7,500 1 to 
8,4001 per cow. Cows were artificially inseminated in natural or synchronized oestruses after 45 days of the voluntary waiting period.

\section{Examination and treatment}

Within the reproductive health programme, periodical transrectal ultrasonographic (USG) examinations were performed in cows on day 5-7 or 11-13 after insemination. Cows with one corpus luteum $(\mathrm{n}=192)$ were included in the study. Based on the results of USG examination, cows were divided into groups according to the diameter of the largest follicle ( $\leq 9 \mathrm{~mm}, 10-14 \mathrm{~mm}$ and 15-20 mm). Randomly selected experimental cows received an intramuscular injection of $0.05 \mathrm{mg}$ synthetic analogue of GnRH lecirelin (Supergestran, Nordic Pharma ${ }^{\circledR}$, Jílové u Prahy, Czech Republic) immediately after the first USG examination on day 5-7 ( $\mathrm{n}=57$, Group E1) or 11-13 $(n=40$, Group E2). The other two groups were control C1 $(n=54)$ and C2 $(n=41)$. The following second and third USG examinations, which aimed to diagnose pregnancy and presence and number of CL, were performed on day 25-39 and around day 90 after insemination.

\section{Blood sampling and progesterone assay}

Blood samples were collected in randomly chosen experimental and control cows (Group E1+ E2, $\mathrm{n}=28$; Group $\mathrm{C} 1+\mathrm{C} 2, \mathrm{n}=18$ ) immediately after the first USG examination (on day 5-7 or 11-13 after insemination). The next blood collection was performed instantly after the second USG examination (on day 25-39 after insemination) only if the cow was diagnosed as pregnant. Peripheral blood was obtained from the coccygeal vein into disposable sampling vacuum plastic tubes (Hemos, GAMA, Ceske Budejovice, Czech Republic) and transfused into tubes with coagulation activator (BD Vacutainer ${ }^{\circledR}$, Becton-Dickenson and Company, Plymouth, UK) after sampling. Each tube was centrifuged $(5 \mathrm{~min}, 2520 \times \mathrm{g}$ ) within 3 or $4 \mathrm{~h}$ after sampling. Serum was stored in Eppendorf microtubes (DISPOLAB s.r.o., Czech Republic) at $-20{ }^{\circ} \mathrm{C}$ until assay. The concentration of progesterone was quantified by sequential competitive immunoassay (IMMULITE ${ }^{\circledR} 1000$, Siemens) in the university laboratory.

Evaluated indicators represented the following: the number of CL in treated and control cows, the number of $\mathrm{CL}$ in treated cows in relation to follicle development; progesterone concentrations in treated and control cows bearing one and two CL and in cows bearing one CL before and two CL after the treatment, conception rate and conception loss in treated and control cows as well as in cows with one and two CL.

\section{Statistical analysis}

Statistical evaluation was performed by $\chi^{2}$ test (chi-squared test; $P<0.0001$ or $P<0.01$ ). Serum progesterone concentration was evaluated by unpaired $t$-test $(P<0.05)$.

\section{Results}

The occurrence of two corpora lutea in the ovaries of treated cows (groups E1 and E2) was markedly higher than in control groups $\mathrm{C} 1$ and C2 (Table 1). Some cows were excluded in all groups E1 14/57 (24.6\%), C1 17/54 (31.5\%), E2 7/40 (17.5\%), C2 18/41 (43.9\%) because they did not bear any CL at second USG examination or showed some pathological symptoms (pyometra, ovarian cysts) between the first and second USG examination.

Table 1. Occurrence of one or two corpora lutea in cows treated with gonadotropin-releasing hormone on days 25-39 as well as in control groups.

\begin{tabular}{lcrrr}
\hline \multirow{2}{*}{ Ultrasound examination } & \multicolumn{2}{c}{ Treated group } & \multicolumn{2}{c}{ Control group } \\
& $2 \mathrm{CL}$ & 1 CL & 2 CL & 1 CL \\
\hline Day 5-7 & $25 / 57(43.9 \%)^{\mathrm{a}}$ & $18 / 57(31.6 \%)$ & $2 / 54(3.7 \%)^{\mathrm{b}}$ & $35 / 54(64.8 \%)$ \\
Day 11-13 & $15 / 40(33.5 \%)^{\mathrm{c}}$ & $18 / 40(45.0 \%)$ & $4 / 41(9.8 \%)^{\mathrm{d}}$ & $19 / 41(46.3 \%)$ \\
\hline
\end{tabular}

${ }^{\mathrm{a}, \mathrm{b}} P<0.0001,{ }^{\mathrm{c}, \mathrm{d}} P=0.0032$

$\mathrm{CL}=$ corpus luteum

In terms of all treated cows (groups E1 and E2), the incidence of two CL was higher in cows bearing the largest follicles $10-14 \mathrm{~mm}(P=0.01)$ or $15-20 \mathrm{~mm}(P=0.06)$ in diameter compared to cows bearing only smaller follicles $\leq 9 \mathrm{~mm}$ in diameter 26/54 $(48.2 \%)$ and $15 / 27(55.6 \%)$ vs. $1 / 15(6.7 \%)$, respectively. One cow did not bear a follicle in the beginning of our study. 
In terms of all experimental cows, serum progesterone concentration was significantly higher in treated cows compared to untreated cows $(7.8 \pm 2.35 \mathrm{ng} / \mathrm{ml}$ vs. $5.9 \pm 2.92$ $\mathrm{ng} / \mathrm{ml} ; P=0.016)$ and it was non-significantly higher $(P=0.05)$ in treated cows bearing two CL compared to treated cows bearing only one CL $(8.1 \pm 2.50 \mathrm{ng} / \mathrm{ml}$ vs. $6.7 \pm 0.99$ $\mathrm{ng} / \mathrm{ml}$ ) on day 25-39 after insemination (second sampling). In addition, progesterone concentration was non-significantly higher in cows with accessory CL at the second sampling on day 25-39 after insemination compared to the same cows bearing one CL before treatment $(8.1 \pm 2.48 \mathrm{ng} / \mathrm{ml}$ vs. $3.8 \pm 1.91 \mathrm{ng} / \mathrm{ml})$.

The conception rate in treated cows bearing two CL was significantly higher $(P<0.0001)$ compared to treated cows with one CL (Table 2). Nevertheless, the total conception rate in treated cows was similar compared to control cows examined on day 5-7 after insemination $(49.1 \%$ vs. $50 \%)$ due to the extremely low conception rate in treated cows with one CL. The total conception rate in treated cows examined was markedly but non-significantly higher compared to control cows on day $11-13$ after insemination (50\% vs. $31.7 \%)$.

Table 2. Conception rate in cows treated with gonadotropin-releasing hormone on days 5-7 and 11-13 after insemination with two or one corpora lutea and in all control cows.

\begin{tabular}{lccc}
\hline Ultrasound examination & Treated (2 CL) & Treated (1 CL) & Control \\
\hline Day 5-7 & $25 / 25(100 \%)^{\mathrm{a}}$ & $3 / 18(16.7 \%)^{\mathrm{b}}$ & $27 / 54(50 \%)$ \\
Day 11-13 & $13 / 15(86.7 \%)^{\mathrm{c}}$ & $7 / 18(38.9 \%)^{\mathrm{d}}$ & $13 / 41(31.7 \%)$ \\
\hline
\end{tabular}

${ }^{\mathrm{a}, \mathrm{b}} P<0.0001,{ }^{\mathrm{c}, \mathrm{d}} P=0.005$

$\mathrm{CL}=$ corpus luteum

Conception loss from day 25-39 until approximately day 90 of pregnancy was higher in control cows bearing one CL compared to treated cows bearing two CL on day 5-7 and on day $11-13$ after insemination ( $16 \%$ vs. $8 \%$ and $22.2 \%$ vs. $7.7 \%$, respectively). Therefore, higher conception rates were found in treated cows compared to controls around day 90 on day 5-7 and on day $11-13$ after insemination (45.6\% vs. $42.6 \%$ and $45 \%$ vs. $26.8 \%$, respectively).

\section{Discussion}

Firstly we focused our attention on the efficiency of induction of accessory corpus luteum by GnRH administration after insemination (AI). Various terms of treatment have been tested in previous studies. MacMillan et al. (1986) found the highest efficiency of treatment on days 11-13 after insemination. The occurrence of two CL was $15 \%$ in cows treated on days 0 and 12 (López-Gatius et al. 2006), 50\% in cows treated on day 5 (Garcia-Inspierto and López-Gatius 2012) and 17.7\% in cows treated on days 28-34 (Bech-Sàbat at al. 2009). However, administration of GnRH on days 5-7 and/or 11-14 after insemination was performed most often (Peters 2005). In our study, we used the terms of 5-7 or 11-13 days after insemination, because in these terms the phase of dominance of the first and second follicular waves can be expected (Evans 2003; Adams et al. 2008). We found higher occurrence of two CL after treatment on day 5-7 compared to day $11-13$ (43.9\% vs. $33.5 \%$ ). The results correspond to findings that the behaviour of the first follicular wave is more standard than the behaviour of the second wave because the beginning and the length of the second follicular wave depend on the number of waves during the oestrous cycle (Price and Carriere 2004; Jaiswal et al. 2009). Unfortunately, there is a lack of data about the efficiency of treatment in relation to the actual stage of follicular development 
on the ovaries. We found higher efficiency of treatment in cows bearing dominant follicles with diameters of 10-14 $\mathrm{mm}$ as well as $15-20 \mathrm{~mm}$ compared to cows bearing only growing follicles with diameters of $\leq 9 \mathrm{~mm}$. The results confirmed our hypothesis that the presence of the dominant follicle increases the efficiency of the GnRH on induction of accessory CL.

Secondly, we evaluated the effect of accessory CL on progesterone concentration and conception. Several authors (López-Gatius et al. 2004; Villarroela et al. 2004; Larson et al. 2007; Bech-Sàbat et al. 2009; Mehni et al. 2012; Pilz et al. 2012) detected higher concentration of progesterone as well as higher conception rate in dairy cows after induction of accessory CL or application of depot forms of progesterone. The conception rate in cows treated by GnRH after AI was higher in the cows with a progesterone concentration above $3 \mathrm{ng} / \mathrm{ml}(40 \%)$ compared to the cows with progesterone below $3 \mathrm{ng} / \mathrm{ml}(18.2 \%)$ (Garcia-Inspierto and López-Gatius 2012). In our study, progesterone concentrations in all treated cows or in treated cows bearing two CL was higher compared to all control cows or to treated cows bearing only one CL on day 25-39 after insemination. In addition, progesterone was markedly lower in pregnant cows with one CL before treatment compared to the same cows with accessory CL after treatment. Several authors confirmed the positive effect of induced accessory CL on the conception rate (López-Gatius et al. 2006; Bech-Sabat et al. 2009; Ataman et al. 2011). In our study, the conception rate was significantly higher in treated cows bearing two CL compared to treated cows bearing only one CL on days 5-7 or 11-13 after AI. We found extremely high conception rates $(100 \%$ and $86.7 \%$ for groups E1 and E2), which were markedly higher in comparison with values in above-mentioned studies. In addition we found lower late embryo/foetal losses until approximately day 90 in treated cows bearing two CL compared to untreated cows bearing only one CL in both terms of GnRH administration (16\% vs. $8 \%$ and $22.2 \%$ vs. $7.7 \%$, respectively). Similar results were described by López-Gatius et al. (2002) who observed pregnancy losses in dairy cows from day 38 to day 90 after insemination. The conception losses $8.7 \%$ and $11.4 \%$ were described by López-Gatius et al. (2004) and Starbuck et al. (2004), respectively. Bech-Sabat et al. (2009) found conception loss $9.9 \%$ in cows treated with GnRH versus $10.7 \%$ in all observed cows.

Our results confirmed a beneficial effect of additional CL not only on progesterone concentration but also on the conception rate. However, the extremely low conception rate $(16.7 \%)$ in unsuccessfully treated cows with only one $\mathrm{CL}$ on days 5-7 remains questionable. We can speculate that successful induction of accessory CL represents the selection of endocrinologically well-balanced cows with higher probability of conception.

In conclusion, administration of GnRH on days 5-7 or 11-13 after insemination induced accessory CL in more than one third of the cows. The induction of accessory CL was more efficient in cows bearing large follicles in time of the treatment and accessory CL increased serum progesterone concentration but without effect on conception rate.

\section{Acknowledgement}

The study was supported by the Internal Grant Agency of the University of Veterinary and Pharmaceutical Sciences Brno 35/2012/FVL and Ministry of Agriculture of the Czech Republic, grant NAZV QI91A238. The authors thank farmers (Agrodruzstvo Blizkovice, Zemedelske druzstvo Kouty, PODYJI a. s. Horni Breckov and Agrodruzstvo Brtov - Lipuvka) for enabling the trial to be performed at their farms and Dr. Vyskocil for statistical evaluation.

\section{References}

Adams GP, Jaiswal R, Singh J, Malhi P 2008: Progress in understanding ovarian follicular dynamics in cattle. Theriogenology 69: 72-80

Ataman MB, Erdem H, Bulbul B, Umutlu S, Colak M 2011: The effect of buserelin injection 12 days after insemination on selected reproductive characteristics in cows. Acta Vet Brno 80: 171-177 
Bech-Sàbat G, López-Gatius F, García-Ispierto I, Santolaria JP, Serrano B, Nogareda C, de Sousa NM, Beckers JF, Yániz J 2009: Pregnancy patterns during the early fetal period in high producing dairy cows treated with GnRH or progesterone. Theriogenology 71: 920-929

Evans ACO 2003: Characteristics of ovarian follicle development in domestic animals. Reprod Domest Anim 38: $240-246$

Garcia-Ispierto I, López-Gatius F 2012: Effects of GnRH or progesterone treatment on day 5 post-AI on plasma progesterone, luteal blood flow and leukocyte counts during the luteal phase in dairy cows. Reprod Domest Anim 47: 224-229

Inskeep EK, Dailey RA 2005: Embryonic death in cattle. Vet Clin N Am-Food A 21: 437-461

Jaiswal RS, Singh J, Marshall L, Adams GP 2009: Repeatability of 2-wave and 3-wave patterns of ovarian follicular development during the bovine estrous cycle. Theriogenology 72: 81-90

Larson SF, Butler WR, Currie WB 2007: Pregnancy rates in lactating dairy cattle following supplementation of progesterone after artificial insemination. Anim Reprod Sci 102: 172-179

López-Gatius F, Santolaria P, Martino A, Delétang F, De Rensis F 2006: The effects of GnRH treatment at the time of $\mathrm{AI}$ and 12 days later on reproductive performance of high producing dairy cows during the warm season in north-eastern Spain. Theriogenology 65: 820-830

López-Gatius F, Santolaria P, Yániz JL, Hunter RHF 2004: Progesterone supplementation during early fetal period reduces pregnancy loss in high-yielding dairy cattle. Theriogenology 62: 1529-1535

López-Gatius F, Santolaria P, Yániz JL, Rutllant J, López-Béjar 2002: Factors affecting pregnancy loss from gestation day 38 to 90 in lactating dairy cows from a single herd. Theriogenology 57: 1251-1261

MacMillan KL, Taufa VK, Day AM 1986: Effects of an agonist of GnRH (buserelin) in cattle. III. Pregnancy rates after a post-insemination injection during metoestrus or dioestrus. Anim Reprod Sci 11: 1-10

Mann GE, Lamming GE 1999: The influence of progesterone during early pregnancy in cattle. Reprod Domest Anim 34: 269-274

Mehni SB, Shabankareh HK, Kazemi-Bonchenari M, Eghbali M 2012: The comparison of treating Holstein dairy cows with progesterone, CIDR and GnRH after insemination on serum progesterone and pregnancy rates. Reprod Domest Anim 47: 131-134

Peters AR 2005: Veterinary clinical application of GnRH - questions of efficacy. Anim Reprod Sci 88: 155-167

Pilz M, Fischer-Tenhagen C, Krueger X, von Thiele G, Heuwieser W 2012: Efficacy of progesterone inserts (CIDR) to reduce early embryonic losses in dairy cows. Tierarztliche Praxis 40: 7-13

Price CA, Carriere PD 2004: Alternate two- and three- follicle wave interovulatory intervals in Holstein heifers monitored for two consecutive estrous cycles. Can J Anim Sci 84: 145-147

Rhinehart JD, Starbuck-Clemmer MJ, Flores JA, Milvae RA, Yao J, Poole DH, Inskeep EK 2009: Low peripheral progesterone and late embryonic/early fetal loss in suckled beef and lactating dairy cows. Theriogenology 71: 480-490

Starbuck MJ, Dailey RA, Inskeep EK 2004: Factors affecting retention of early pregnancy in dairy cattle. Anim Reprod Sci 84: 27-39

Villarroela A, Martinob A, BonDuranta, RH, Francois Dèletang, Sischoa WM 2004: Effect of post insemination supplementation with PRID on pregnancy in repeat-breeder Holstein cows. Theriogenology 61: 1513-1520

Walsh SW, Williams EJ, Evans ACO 2011: A review of the causes of poor fertility in high milk producing dairy cows. Anim Reprod Sci 123: 127-138 